\title{
Acoustic Testing for Phonologization
}

\author{
Kimary Shahin \\ Dept. of Linguistics, Simon Fraser University, 8888 University Drive, Burnaby, Canada V5A 1S6
}

\section{INTRODUCTION}

Phonologization $[1,2]$ occurs when some variation in production occurs with frequency and is stabilized as a new pattern [1, 3]. The Optimality Theory grammar of a language is its constraint ranking. Phonologization occurs when categorical, non-numeric versions of numerically weighted phonetic constraints [4] enter the strict dominance relations of the grammar. This paper examines how this shift arises from the acoustic signal, focusing on gradience [5] in postvelar phenomena in Salish and Arabic.

\section{PHONETIC TO PHONOLOGICAL OPTIMIZATION}

Flemming [4] proposes that phonetic properties can be understood as the effect of the interaction of weighted constraints. He explains it as follows. In CV sequences, e.g., $\mathrm{F}_{2}$ of the $\mathrm{C}$ and $\mathrm{V}$ are co-determined by a constraint against deviation from $\mathrm{C}$ and $\mathrm{V} \mathrm{F}_{2}$ targets and a constraint against quick articulator movement. Achieving both targets could mean quick speech, and slow movement could mean achieving neither target. The actual production is an optimization of this conflict. The constraint weighting is such that both targets are undershot. Degree of undershoot depends on exact weighting. In this model, the weightings figure into a mathematical cost function which determines the optimization, e.g.:

(1) Flemming's cost function for F2 in CV [4]

$$
c=w_{c}\left(F 2_{C}-F 2_{L}\right)^{2}+w_{\nu}\left(F 2_{V}-F 2_{T}\right)^{2}+w_{e}\left(F 2_{C}-F 2_{V}\right)^{2}
$$

where $F 2_{C}$ is $\mathrm{F}_{2}$ of the $\mathrm{C}, F 2_{V}$ is $\mathrm{F}_{2}$ of the $\mathrm{V}, F 2_{L}$ is fixed target $\mathrm{F}_{2}$ of the $\mathrm{C}, F 2_{T}$ is fixed target $\mathrm{F}_{2}$ of the $\mathrm{V}$, and $w_{c}, w_{v}$ and $w_{e}$ are positive weights.

The first two terms express 'Don't deviate from targets' separately for $\mathrm{C}$ and $\mathrm{V}$. If the differences are minimal, cost on contrast will be minimal. The overall cost also includes cost on effort. This is that incurred by the difference between $F 2_{C}$ and $F 2_{V}$, as specified by the last term of the function, which expresses 'Don't move quickly'. If the difference is small, the articulators move quickly. As stated by Flemming, weighted constraints compute costs in real numbers. They reflect the scalar nature of phonetic factors and their additive effects.

This differs from the phonological grammar, as illustrated in (2). ALIGN-TR, with phonetic basis in $w_{e}\left(F 2_{C}-\right.$ $\left.F 2_{V}\right)^{2}$, requires [TR], the phonological feature implemented as tongue root articulation, to be aligned with the word edges. IDENT, with phonetic basis in $w_{c}\left(F 2_{C}-F 2_{L}\right)^{2}+w_{v}\left(F 2_{V}-\right.$ $\left.F 2_{T}\right)^{2}$, requires that there be no feature change between input and output. In (2), the input is between slashes; competing outputs are between square brackets. Output candidate $b$ is optimal because it best satisfies the two discrete constraints, given their ranking: it satisfies the higher ranked ALIGN-TR whereas candidate a violates it ('*'), fatally so ('!').

As phonetic properties are gradient but phonological properties are not, a key trigger for the shift between the phonetics and phonology is degree of gradience.
(2)

\begin{tabular}{|c|c|c|}
\hline /ta/ & ALIGN-TR & IDENT \\
\hline a. [ta] & $* !$ & \\
\hline b. $\lceil\underline{\mathrm{ta}}\rceil$ & & $*$ \\
\hline
\end{tabular}

\section{ACOUSTIC STUDY}

\subsection{Method and procedure}

St'át'imcets Salish words were produced by an adult male native speaker, aged 68 years. Palestinian Arabic words were produced by an adult male native speaker, aged 45. See the Appendix. For St'át'imcets, $60 \mathrm{~V}$ tokens and 72 $\mathrm{C}$ tokens were analyzed. For Palestinian, $120 \mathrm{~V}$ tokens were analyzed. Recording used a Marantz P420 tape recorder. Digitization was at $22.05 \mathrm{kHz}$ sampling rate. Analysis used Multi-Speech $3700 . \mathrm{F}_{1}$ and $\mathrm{F}_{2}$ of $\mathrm{Vs}$ and approximants were measured. The resonance in the area of $\mathrm{F}_{2}$ was measured for fricatives, and stops (in the release burst). Measurements were at durational midpoint. Formant (' $F$ ') centre frequency was taken as the average of values obtained from wide and narrowband spectrograms using the values provided by Multi-Speech 3700 with placement of the cursor on the estimated $\mathrm{F}$ centre.

\subsection{Results: St'át'imcets Salish}

Figs. 1-3 present data from St'át'imcets relevant to uvularization spread, lowering of [ə] before [?], and lowering of labialized uvulars. F means (in Hz) and standard deviations (SDs) are shown. SD is used here to determine if a property is gradient, as phonetic properties vary more than phonological ones [5]. Fig. 1 shows that $\mathrm{F}_{2}$ is dropped for [a] preceding and following a uvularized $\mathrm{C}$ (' $\mathrm{C}$ '). $\mathrm{F}_{1}$ is raised in both cases. The effects are greater preceding. The SDs provide no evidence for identifying the greater $F$ effects preceding the $\underline{\mathrm{C}}$ as phonological: $\mathrm{F}_{2} \mathrm{SD}$ in that case is even greater than $\mathrm{F}_{2} \mathrm{SD}$ for [a] following a $\underline{\mathrm{C}}$ (86 vs. 46). This counters usual assumption that the leftward coarticulation is phonological in this language. Fig. 2 shows that [ə] is lowered preceding [?], as $\mathrm{F}_{1}$ is raised in that context. The $\mathrm{F}_{1}$ SD is lower preceding [?] than preceding C (61 vs. 71). This indicates that the [ə] lowering, considered phonetic in this language, is perhaps becoming phonologized. For Fig. 3 we focus on $\mathrm{F}_{2}$, the one resonance measurable for all $\mathrm{C}$ types. The labialized uvulars, including $\left[\underline{x}^{w}\right]\left(\left[\chi^{w}\right]\right)$ and $\left[k()^{w}\right]$ $\left(\left[q\left({ }^{\prime}\right)^{w}\right]\right)$, show a drop in ' $F_{2}$ ', as expected. $F_{2} S D$ is lower for $\left[\mathrm{B}\left({ }^{\prime}\right)^{\mathrm{w}}\right]$ than for $[\mathrm{B}(')]$ (31 vs. 69), indicating that the lowered $\mathrm{F}_{2}$ for $\left[\mathrm{B}\left(\mathrm{C}^{\prime}\right)^{\mathrm{w}}\right]$ phonological. The $\left[\mathrm{B}\left({ }^{\prime}\right)^{\mathrm{w}}\right]$ is produced with auditorily perceptible pharyngeal articulation, and is $\left[\mathrm{S}\left(\mathrm{C}^{\mathrm{w}}\right]\right.$. The lower $\mathrm{F}_{2}$ of pharyngeal compared to uvular articulation enhances the lower $F_{2}$ of the labialization. For $\left[x^{w}\right]$ and $\left[\underline{k}(')^{w}\right]$ the variation in $F_{2}$ is greater than for their plain variants, indicating that their $F_{2}$ drop with labialization is phonetic. The $\left[\mathrm{x}^{\mathrm{w}}\right]$ and $\left[\underline{k}\left({ }^{\prime}\right)^{\mathrm{w}}\right]$ are not perceptibly pharyngeal, i.e., they are not $\left[\hbar^{w}\right]$ and $\left[\mathbf{f}()^{\mathrm{w}}\right]$. 


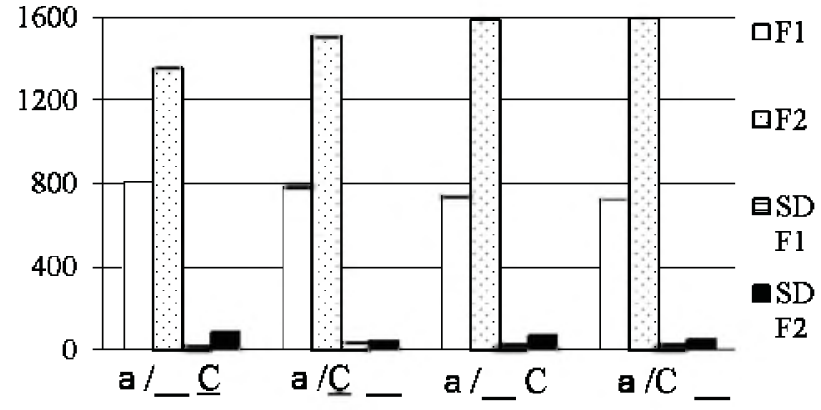

Fig. 1. $F_{1}$ and $F_{2}$ of $S t$ 'át'imcets $V s$ in $C-V / V-C$ sequences

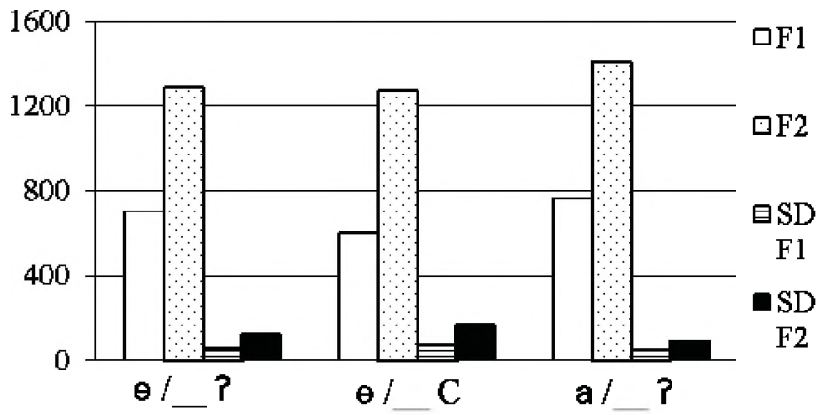

Fig. 2. $F_{1}$ and $F_{2}$ of St'át'imcets [ə] and [a] before [?]

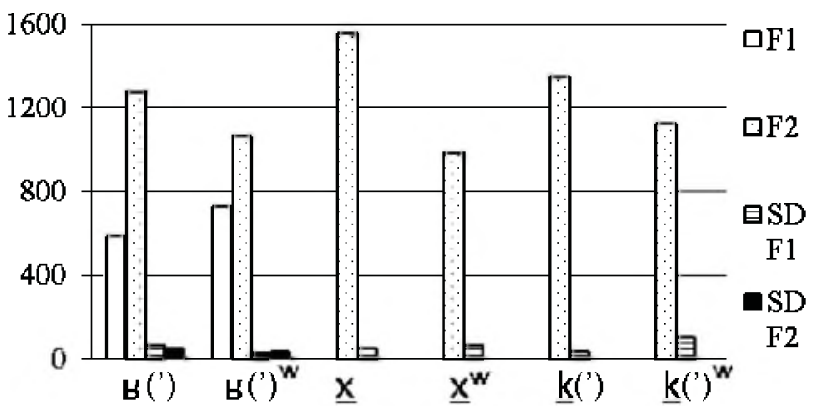

Fig. 3. Resonances of non-labialized and labialized St'át'imcets uvulars

\subsection{Results: Palestinian Arabic}

Fig.4 presents data from Palestinian relevant to uvularization of the low V ('A'), opacity to uvularization spread by the high front V ('I'), and lack of pharyngealization for a stem-final $V$, which was ' $U$ ' in the carrier word [6]. We take 40 as normal SD for Fs of a distinct sample [7]. SDs of $19.2\left(\mathrm{~F}_{1}\right)$ and $29.8\left(\mathrm{~F}_{2}\right)$ for uvularized $\mathrm{A}$ indicate that its coarticulation is phonological. SDs of $13.7\left(\mathrm{~F}_{1}\right)$ and 31.7 $\left(\mathrm{F}_{2}\right)$ for I adjacent to $\mathrm{C}$ indicate phonological lack of coarticulation for that $\mathrm{V}$. In this language, $\mathrm{Vs}$ in closed syllables are pharyngealized (i.e., become rtr) except when stem-final. SDs of $30.2\left(\mathrm{~F}_{1}\right)$ and $52.7\left(\mathrm{~F}_{2}\right)$ for closedsyllable, stem-final $U$ indicate that that rtr quality for stemfinal Vs is perhaps becoming phonologized.'

\section{CONCLUSION}

This work illustrates acoustic testing for phonologization. Gradience was examined and found to underlie phonologized patterns, and to indicate that certain patterns previously considered phonological are perhaps phonetic.

1 Other SDs from the data are: $13.2\left(\mathrm{~F}_{1}\right), 15.9\left(\mathrm{~F}_{2}\right)$ for nonuvularized $\mathrm{A} ; 8.4\left(\mathrm{~F}_{1}\right), 27.8\left(\mathrm{~F}_{2}\right)$ for I not adjacent to $\underline{\mathrm{C}} ; 9.1$ $\left(\mathrm{F}_{1}\right), 17.8\left(\mathrm{~F}_{2}\right)$ for closed syllable, non-stem-final $\mathrm{U}$.
F2 $(\mathrm{Hz})$

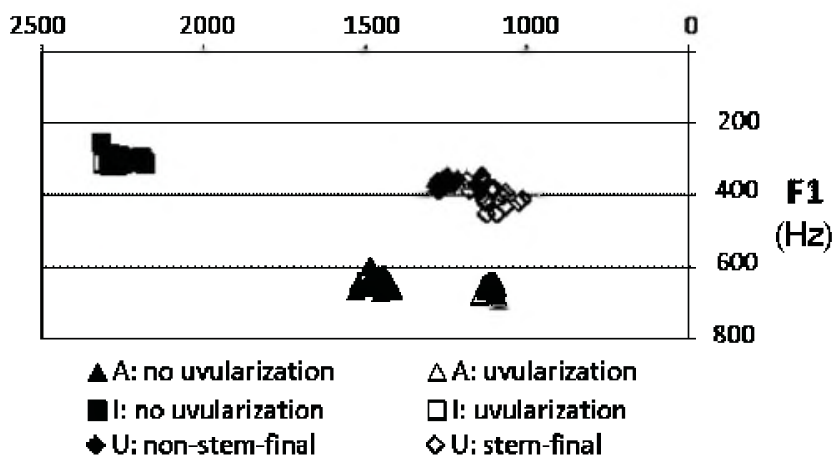

Fig. 4. $F_{1}, F_{2}$ plot of Palestinian Vs in postvelar contexts

\section{REFERENCES}

[1] J. J. Ohala (1981). The listener as source of sound change. P.178-203 in C. S. Masek, R. A. Hendrick and M. F. Miller (eds.), Papers from the parasession on language and behavior. Chicago Ling. Soc.

[2] B. Hume (2008). Expectation and its role in phonologization and language change. Talk at the Symposium on Phonologization, Chicago, April 25, 2008.

[3] B. Hayes and D. Steriade (2004). Introduction: The phonetic basis of phonological markedness. P.1-32 in B. Hayes, R. Kirchner and D. Steriade (2004), Phonetically-based phonology. Cambridge. [4] E. Flemming (1997). Phonetic optimization: compromise in speech production. In B. Moren and V. Miglio (eds.), U Maryland WPL 5 .

[5] S. Meyers (2000). Boundary disputes: the distinction between phonetic and phonological sound patterns. P.254-72 in N. BurtonRoberts, P. Carr and G. Docherty (eds.), Phonological knowledge: conceptual and empirical issues. Oxford.

[6] K. Shahin (2002). Postvelar harmony. Benjamins.

[7] B. Lindblom (1962). Phonetics Congress talk.

\section{ACKNOWLEDGMENTS}

Thanks to Elder Herman Dan and to Khaled Shahin for providing the acoustic data for this study. The support of the Jacobs Fund and the Lower Stl'atl'imx Tribal Council is gratefully acknowledged.

\section{APPENDIX}

For each word, the number of tokens recorded is given in parentheses."

A. St'át'imcets words recorded for the acoustic study
a. Pax ${ }^{\mathrm{w} x a l}$
'dig' (6)
b. $x^{w} \partial$ Paz
'no, not' (2)
c. maqa?
'snow' (6)
d. mexał
'black bear' (6)
e. qəPoz'?ul
'tired out' (2)
f. qəPamaj' $\phi$ 'breastfeed' (2)
g. mə?əь'
'dawn' (4)
h. рәРәв'
'pale, faded' (2)
i. təwæn
'salmon berry' (2) j. təqiw
'horse' (2)
k. zəhaka?
'right hand' (2)
1. zəwaten 'know' (2)
m. wənax ${ }^{w}$ t' 'u? 'true' (2)
o. $\mathrm{q}^{\text {'w }}$ ijgqin 'axe' (2)
q. $\chi^{\mathrm{w}} \mathrm{a}$ ?
'sockeye' (6)
n. $\chi^{\text {w }}$ umqa? 'salmon head' (6)
s. wəsən
p. ts'uq"az' 'small fish' (6)
u. bawan
'sort s.t.' (2)
r. $\chi a \chi t 5 a ? \quad$ (name of Band) (6)
t. k'i?is'w 'feel run down' (2)
w. kantisw"a 'swallow s.t. wrong' (2) $\quad$ x. q'w $ә \boldsymbol{w}^{\mathrm{w} p}$ 'slide down' (4)

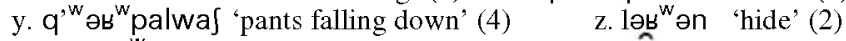
a'. məlux waka? 'sprain one's hand' (2) b'. zi? zәь t中'u? 'always' (2)
c'. kan屯is" kana 'I swallowed s.t. wrong' (2) d'. s"uj't 'sleep' (2)
e'. PəPХa? 'sacred, supernatural talented' (2)

B. Palestinian words recorded for the acoustic study

$\begin{array}{llll}\text { a. kəsæ:t } & \text { 'cups' }(20) & \text { b. bəs:a:t } & \text { 'busses (20) } \\ \text { c. ti:n } & \text { 'fig' }(20) & \text { d. ti:n } & \text { 'mud' }(20) \\ \text { e. ful:e } & \text { (type of doll) (20) } & \text { f. bisekfu-Inæ:S 'they don't } \\ & & & \end{array}$

* IPA is used. Underlining denotes uvularization. The hyphen in $\mathrm{B}(\mathrm{f})$ indicates that the $[\mathrm{u}]$ in that word is at a right stem edge. 